кандидат юридических наук, доцент, ведущий научный сотрудник Всероссийского научно-исследовательского института МВД Российской Федерации

\section{ПРОБЛЕМНЫЕ ВОПРОСЫ ПРОФИЛАКТИКИ НАСИЛЬСТВЕННЫХ ПРЕСТУПЛЕНИЙ В ОТНОШЕНИИ ЛИЦ, НАХОДЯЩИХСЯ В БЕСПОМОЩНОМ СОСТОЯНИИ}

\footnotetext{
Аннотация:

В статье раскрывается понятие беспомощного состояния потерпевшего, анализируются особенности уголовно-правовой оценки беспомощности потерпевших, квалификации преступлений в их отношении. Предложены конкретные рекомендации в целях виктимологической профилактики насильственных преступлений против лиц, находящихся в беспомощном состоянии, снижения уровня латентности, остановки процесса викти мизации, снижения вторичной виктимизации.

\section{Ключевые слова:}

потерпевший, насильственные преступления, беспомощность, виктимность, квалификация, виктимологическая профилактика.
}

PhD in Law, Assistant Professor, Leading Research Associate, All-Russian Research Institute, Ministry of Internal Affairs of Russia

\section{PROBLEMATIC ISSUES OF PREVENTION OF VIOLENT CRIMES AGAINST HELPLESS PERSONS}

Summary:

The article deals with the concept of helpless condition of a victim, analyses the peculiarities of the criminallegal assessment of victims' helplessness, classification of crimes against helpless persons. The author suggests specific measures focused on prevention of violent crimes against helpless persons, reduction of dormancy level, interrupting of the victimization process, and reduction of the secondary victimization.

Keywords:

victim, violent crime, helplessness, victimization, clas sification, victimologic prevention.

В связи с высоким уровнем преступности в стране актуализируется необходимость всесторонней защиты прав и интересов потерпевших.

Так, по данным ГИАЦ МВД России, в 2013 г. на территории Российской Федерации было зарегистрировано 226594 насильственных преступления, в 2014 г. - 189 084, в 2015 г. 175256 [1], при этом тенденция снижения количества зарегистрированных насильственных преступлений далеко не адекватно отражает реальную динамику фрактической преступности, которая может быть объяснена как усилением процесса укрытия преступлений от учета и регистрации, устойчиво охватившего регионы страны и не встречавшего соответствующего противодействия, так и снижением активности правоохранительных органов по выявлению преступлений.

Насильственная преступность, как и прежде, занимает значительное место в ряду преступных посягательств, совершаемых на территории страны, что является отражением не только обострения криминогенной обстановки, но и острой необходимости в научных разработках, использование которых позволит снизить уровень виктимизации общества, удовлетворить потребности практики в рекомендациях по совершенствованию правоприменительной деятельности.

По данным ГИАЦ МВД России, ежегодно совершается около 2 млн преступлений, и, соответственно, около 1,5 млн физических и юридических лиц оказываются потерпевшими (2008 г. 2340 375, 2009 г. - 2241 710, 2010 г. - 2062 937, 2011 г. - 1924 192, 2012 г. - 1895 970, 2013 г. 1822 767, 2014 г. - 1819 811). Материальный ущерб, нанесенный потерпевшим в 2015 г., составил около 550 млрд р. [2], что свидетельствует о сложной криминогенной обстановке, наличии в российском обществе тревожной тенденции, которая выражается в высоком уровне жестокости, незащищенности человека от преступного насилия.

По данным ГИАЦ МВД России, ежегодно совершается около 2 млн преступлений, и соответственно около 1,5 млн фризических и юридических лиц оказываются потерпевшими (2008 г. 2340 375, 2009 г. - 2241 710, 2010 г. -2062 937, 2011 г. - 1924 192, 2012 г. - 1895 970, 2013 г. 1822 767, 2014 г. - 1819 811), материальный ущерб, нанесенный потерпевшим в 2015 г., составил около 550 млрд рублей [2], что свидетельствует о сложной криминогенной обстановке, наличии в российском обществе тревожной тенденции, которая выражается в высоком уровне жестокости, незащищенности человека от преступного насилия.

Понятие беспомощности потерпевшего давно перешагнуло рамки некоего элемента в контексте отдельных составов преступлений, приобрело глобальный характер, затрагивает не только 
материальное, но и процессуальное право. В юридической науке среди ученых отсутствует единообразное понимание термина «беспомощное состояние потерпевшего», имеющего уголовно-правовое и криминологическое значение, не определены критерии его оценки [3, с. 41; 4, с. 125].

Понятие беспомощности потерпевшего давно перешагнуло рамки некоего элемента в контексте отдельных составов преступлений, приобрело глобальный характер, затрагивает не только материальное, но и процессуальное право. В юридической науке, среди ученых отсутствует единообразное понимание «беспомощное состояние потерпевшего», имеющее уголовноправовое и криминологическое значение, не определены критерии его оценки [3, с. 41; 4, с. 125].

Так, в Законе РФ от 02.07.1992 № 3185-1 (ред. от 03.07.2016) «О психиатрической помощи и гарантиях прав граждан при ее оказании» беспомощное состояние потерпевшего интерпретируется как неспособность лица самостоятельно удовлетворять основные жизненные потребности.

Беспомощное состояние человека, в какой бы форме оно ни проявилось (потеря сознания при диабетической коме, из-за приступа стенокардии, эпилептического припадка и т. п. или обморочного состояния - из-за стресса, теплового удара и др.) и независимо от того, что спровоцировало его возникновение и какой промежуток времени оно длилось, в полном объеме лишает лицо возможности выразить свою волю, а тем более принять меры по самосохранению, если в этот период происходит посягательство криминального характера [5, с. 56].

Беспомощное состояние потерпевшего в уголовно-правовом смысле рассматривается нами как физическое, психическое или психофизиологическое состояние человека, при котором он лишен способности принимать меры, необходимые для самосохранения, в момент преступного посягательства на его жизнь, что обусловлено тяжким заболеванием, психическим расстройством, возрастом, умственной неразвитостью или бессознательным состоянием, иными внешними фракторами.

В связи с повышением уровня виктимизации лиц, находящихся в беспомощном состоянии, все наиболее актуальными становятся проблемы разработки конкретных рекомендаций по профилактике, направленной на выявление, устранение или нейтрализацию факторов, обстоятельств, ситуаций, формирующих виктимное поведение данной категории потерпевших, снижение их вторичной виктимизации, обеспечение их виктимологической безопасности.

Кроме того, негативные последствия для физического и психологического здоровья от преступного насилия для данной категории потерпевших требуют порой от органов внутренних дел принятия экстренных и действенных мер для их предотвращения. Беспомощный потерпевший чаще всего вынужден сам добиваться защиты своих прав, получая при этом дополнительные неудобства и страдания.

Не в полной мере разработанные на законодательном уровне конкретные рекомендации по квалификации преступлений, совершаемых в отношении беспомощных потерпевших, которые могут оказать существенную помощь сотрудникам правоохранительных органов при расследовании данной категории дел, слабо изученные психологические особенности беспомощных потерпевших, механизмы влияния различных сенсорных и умственных дефектов на поведение потерпевшего, особенности виктимности беспомощных потерпевших как криминогенного фактора, влияющего на повышение степени общественной опасности преступных посягательств, актуализируют необходимость совершенствования теоретических, правовых и организационных основ охраны прав, свобод и законных интересов беспомощных потерпевших от посягательств криминального характера.

В этих условиях формирование государственной виктимологической политики как самостоятельного направления криминологической политики, включающей в себя виктимологическую профрилактику, систему общесоциальных и специальных мер, направленных на снижение виктимного поведения беспомощных жертв преступных посягательств, связано с устранением, нейтрализацией или уменьшением факторов, обусловливающих или способствующих их виктимизации.

Беспомощное состояние потерпевшего в виктимологическом смысле представляет собой неспособность потерпевшего в силу повышенной виктимности (особое физическое и психическое состояние: психическое расстройство, инвалидность и т. д.) осознавать характер криминального насилия и оказывать сопротивление виновному лицу.

С целью виктимологической профилактики насильственных преступлений против лиц, находящихся в беспомощном состоянии, снижения уровня латентности, остановки процесса виктимизации, снижения вторичной виктимизации в правохранительной деятельности необходимо:

- усовершенствовать статистические данные, на основании п. 7 ст. 17 Федерального закона «О полиции» классифицировать в соответствии с количественными и качественными показателями, а также группами и видами преступлений информационные базы по беспомощным потерпевшим; при оценке количественных показателей применять коэффрициент виктимности и скорость прироста (уменьшения) уровня виктимности по сравнению с аналогичным периодом; 
- приказы МВД РФ дополнить положениями, относящимися к виктимологической профилактике правонарушений, определив в них цели, задачи и критерии оценки такого фрункционирования, а также детализировать права и обязанности сотрудников полиции по его реализации в отношении беспомощных потерпевших;

- разработать программу с пошаговым алгоритмом, регулирующую процесс взаимодействия сотрудника с данной категорией потерпевших с учетом их психологических и физиологических особенностей (структура беседы, оказание помощи консультативного характера и т. д.);

- ввести для сотрудников правоохранительных органов обязательный курс виктимологической подготовки с целью увеличения результативности проводимых ими профилактических мер виктимологической направленности.

Таким образом, комплексное использование возможностей виктимологической профилактики, ориентированной прежде всего на охрану прав, свобод и законных интересов беспомощных потерпевших от насильственных преступлений, в совокупности с иными мерами предупредительного воздействия будет содействовать уменьшению уровня преступности и стабилизации криминогенной обстановки в целом.

\section{Ссылки:}

1. Официальный сайт МВД РФ [Электронный ресурc]. URL: https://mvd.ru/request_main (дата обращения: 26.11.2016).

2. Верховный суд РФ [Электронный ресурc]. URL: https://vsrf.ru/request main (дата обращения: 26.11.2016).

3. Салева Н.Н. Проблема учета беспомощного состояния потерпевшего при квалификации сопряженного убийства, предусмотренного п. «К» Ч. 2 ст. 105 УК РФ // Уголовное право. 2006. № 9. С. 41.

4. Веселов Е.Г. Физическое или психическое принуждение как обстоятельство, исключающее преступность деяния : дис. ... канд. юрид. наук. Краснодар, 2002. С. 125.

5. Задорожный В.И. Виктимологическая безопасность и ее обеспечение мерами виктимологической профилактики : монография. Тамбов, 2005. С. 56.

\section{References:}

Saleva, NN 2006, 'The problem of consideration of the victim's helpless state during qualification of the related murder, stipulated in paragraph "k", part 2, article 105 of the Criminal Code of the Russian Federation', Ugolovnoye parvo, no. 9, p. 41, (in Russian).

Veselov, EG 2002, Physical or mental compulsion as a circumstance excluding the criminality of the act, PhD in Law thesis, Krasnodar, p. 125, (in Russian).

Zadorozhny, VI 2005, Victimological safety and its provision with measures of victimological prevention, monograph, Tambov, p. 56, (in Russian). 